\title{
Neither demarcation nor confrontation
}

\section{Finding a critical position towards right-wing populism}

\author{
Christoph Haker · Lukas Otterspeer $($ D
}

Received: 7 July 2020 / Revised: 27 October 2020 / Accepted: 29 October 2020 / Published online: 27 November 2020

(C) The Author(s) 2020

\begin{abstract}
Right-wing populism has strongly polarizing effects in politics, education and science-a problem which this article aims to adress. Instead of claiming a demarcation between science and education on the one hand and right-wing populist ideology on the other, we initially focus on continuities. At the same time, we are concerned with finding a critical distance towards right-wing populism. Using the theoretical framework of boundary-work we therefore analyse a case of right-wing populist educational and scientific efforts. Boundary-work can occur in an institutional, content-related and epistemic dimension. While we identify strong continuities in the institutional and content-related dimensions, we see the main difference in the epistemic dimension. In conclusion, we use the results of our analysis to develop a critical position as scientists and educationists towards right-wing populism, drawing consequences for the epistemic, content-related and institutional dimensions.
\end{abstract}

Keywords Education · Bildung $\cdot$ Science $\cdot$ Epistemology $\cdot$ Right-wing populism • Far Right

\footnotetext{
Dr. phil. C. Haker

Heinrich-Hertz-Schule Hamburg, Grasweg 72-76, 22303 Hamburg, Germany

E-Mail: christoph.haker@gmail.com

Dr. phil. L. Otterspeer $(\bowtie)$

Institut für Allgemeine Didaktik und Schulpädagogik (IADS), Technische Universität Dortmund, Emil-Figge-Straße 50, 44227 Dortmund, Germany

E-Mail: lukas.otterspeer@tu-dortmund.de
} 


\section{Weder Demarkation noch Konfrontation}

Eine kritische Positionierung zum Rechtspopulismus

Zusammenfassung Rechtspopulismus polarisiert in Politik, Bildung und Wissenschaft. Anstatt sich an dieser Polarisierung zu beteiligen und eine Abgrenzung zwischen Wissenschaft und Bildung auf der einen Seite und Rechtspopulismus auf der anderen Seite vorschnell zu markieren, fokussieren wir zunächst auf Kontinuitäten. Zugleich geht es uns darum, eine kritische Distanz zum Rechtspopulismus zu finden. Deshalb analysieren wir einen Fall rechtspopulistischer Bildungsarbeit und Bemühungen um Wissenschaftlichkeit mit dem theoretischen Rahmen des boundary-work. Diese Grenzarbeit kann sich in einer institutionellen, inhaltlichen und epistemischen Dimension vollziehen. Während wir starke Kontinuitäten auf der institutionellen und inhaltlichen Ebene herausarbeiten, zeigt sich der Hauptunterschied in der epistemischen Dimension. Schlussfolgernd verwenden wir die Ergebnisse unserer Analyse, um eine kritische Position als Wissenschaftler und Lehrende gegenüber dem Rechtspopulismus zu entwickeln. Dabei ziehen wir erste Konsequenzen auf der epistemischen, inhaltlichen und institutionellen Dimension.

Schlüsselwörter Bildung $\cdot$ Wissenschaft $\cdot$ Epistemologie $\cdot$ Rechtspopulismus

What is at stake is an uncertainty about the direction that paradoxically enables successful advancement. Thus, the immanence of the boundaries of knowledge and the precariousness of the knowledge horizon not only determine, but also constitute the space of knowledge acquisition (Rheinberger 2019, p. 12-13).

\section{Between demarcation and confrontation}

Right-wing populists polarize in public debates not only through their own statements. They also polarize when people talk about them. Specifically, the question of whether and how to deal with right-wing populism is hotly debated in public (for the German discourse, see Leo et al. 2017; Czollek 2018) and in the field of educational and social science (Andresen 2018; Thompson 2020). "Educational institutions and universities in particular are challenged by the anti-pluralist, antiexpert and anti-elitist stance of populist movements, in particular those on the right" (Waller et al. 2017, p. 384). We consider it necessary to respond to this challenge in a specific educational and scientific way because the right-wing hegemony project (on hegemony projects, see Buckel et al. 2017) is not limited to the political sphere but also relates to education ${ }^{1}$ and science. Therefore, we focus our boundary-work on education and science, since far right intellectual organizations (Mudde 2019) raise both a scientific and educational claim. At the same time we emphasise that

\footnotetext{
${ }^{1}$ When we use the term "education" in the following, we mean the educational system or areas of educational practices. When we refer to education as individual development, as a process of opening up the world, we use the German term "Bildung".
} 
Bildung and science are closely intertwined-not least in our own practice as scientists and teachers in higher and adult education. By finding a critical position towards right-wing populism, we are addressing colleagues in science and/or (adult) education who are looking for ways to deal with phenomena of right-wing populism, in particular in research and/or teaching.

This article examines the relationship between right-wing populism and science and education. Our main goal is to gain a better understanding of the boundary-work (Gieryn 1983) between these fields, instead of proclaiming a solid border between science and educational work on the one hand, and right-wing populism on the other. $^{2}$ By adopting this approach, we reject the demarcation position as a starting point for our research. In contrast, we begin with an interest in the practices that draw or diminish boundaries. Our analysis thus aims for a better understanding of right-wing populist boundary-work towards education and science and then, in a self-critical turn, intends to question our own practice. In doing so, we reject the position of confrontation. Our primary goal is not to convince right-wing populist actors but to show how education and science can immanently oppose right-wing populist appropriation by understanding science and Bildung as processes that go hand in hand. We are thus concerned with our own practice as scientists and teachers in higher and adult education.

Recent studies have explored the connection between science and education on the one hand and right wing populism on the other (for an overview, see also Rödel 2020). The following brief insight into the state of research underlines that the black and white demarcation towards right-wing populism is empirically questionable and requires further research: Sabine Andresen (2018) elaborates how right-wing populism mobilizes along the issues of childhood, family and education and therefore does in part pertain to educational professions. This is also shown by Werner Thole (2020) in the context of social work. In our own research (Otterspeer and Haker 2019; Haker and Otterspeer 2021) we point out that educational and social science are used in far right contexts to gain scientific authority. Christiane Thompson (2020) correctly identifies the conflict as to whether right-wing populist discourse and thinking should be confronted within the university setting or banned from the universities altogether. This debate thus illustrates that there are no undisputed boundaries between university and right-wing populism. Furthermore, the thesis that constructivist or poststructuralist theory have contributed to the rise of right-wing actors (Hampe 2016; Amlinger 2020; from a critical perspective, Vogelmann 2019) shows that there is no consensus on a clear separation between science and rightwing populism.

While most of these studies have focused mainly on the blurred borders betwen education, science and right-wing populism, there is limited research investigating the practice of boundary-work. We close this research gap, by asking: How is the

\footnotetext{
2 We see this kind of solid demarcation when researchers tend to draw a clear dividing line between themselves and right-wing populism as the difference between facts and fake. This stance is reflected in slogans like "Facts First!" or "There is no Alternative to Facts!" in the March for Science. This less analytical and more strategical demarcation is problematic because it tends to be scientocratic (Strohschneider 2017) and ignores the preliminary status of scientific knowledge.
} 
specific boundary constituted between our understanding of science and education and that of right-wing populism? What are the continuities between science and education on the one hand and right-wing populism on the other? How can, despite these continuities, a critical distance to right-wing populism be maintained which does not fall into the misconstruction of the black and white demarcation outlined above? Demarcation and confrontation as immediate reflexes to right-wing populism bar the way to such an analysis as they do not allow an open process of reflection on our relationship towards right-wing populism. Instead of hastily drawn boundaries which ultimately suggest that the central difference to right-wing populism is simply a political difference, we thus want to open the perspective towards more complex boundary-work that allows to take a critical position from the perspective of Bildung and science. ${ }^{3}$ To put it very clearly: since right-wing populist ways of thought and belief are booming and we-scientists and educationists in higher and adult education - are not simply immunized either, we consider it necessary to actively work on a critical positioning (see also Rödel (2020) who currently asks how a metapoliticization of the field of adult education can be countered).

This paper is organized into three main parts, the first of which describes our theoretical framework. Our perspective in this regard is located in the field of science studies with strong ties to political theory. We make use of the concept of boundarywork (Gieryn 1983) by interweaving it with perspectives from the political theory of right-wing populism. We apply this approach by analysing a conference held by a far right think tank in Germany which claims to be scientific and sees itself as an educational institution. Part two details the findings of our research on the boundary-work of this far right think tank, referring to its website, the documentation of the conference on the internet as well as to print publications. In the third and concluding part we develop a critical position towards right-wing populism that is primarily based on our scientific and educational assumptions and focusses on our own practices.

\section{Boundary-work between science and non-science}

Our theoretical framework is based on the concept of boundary-work developed by Thomas F. Gieryn. In his understanding, boundary-work is the construction of boundaries "between science and varieties of non-science" (Gieryn 1983, p. 781). The core assumption behind this concept is that "boundaries of science are ambiguous, flexible, historically changing, contextually variable, internally inconsistent, and sometimes disputed" (Gieryn 1983, p. 792). Gieryn's approach is located in the field of historical epistemology and science studies. But as Gieryn (1999) shows, boundary-work is not limited to the differentiation between science and non-science. We

\footnotetext{
3 We are therefore critical of the fact that the analysis of right-wing populism in some cases simply speaks of opponents (see for example https://gegneranalyse.libmod.de/ (access on: 2020, October 14)). Speaking of opponents tends to imply meeting them at eye level in the struggle for the respective object. By applying boundary-work, however, we want to show that such an encounter on an equal level lacks some prerequisites - to then ask first and foremost how we ourselves can cope with these challenges.
} 
are therefore going to use this theoretical framework also to analyse the boundarywork in the field of education. It is furthermore important to note right from the start that scientific and educational boundary-work cannot only mean constructing a demarcation between oneself and others by highlighting major differences. It can also mean establishing similarities that force the others to acknowledge oneself as a scientific actor. Boundary-work in this sense is always a challenge in which both sides are involved.

The concept of boundary-work can be used in two ways. First, it can be applied to analyze how someone claims to be a scientist, gains scientific authority or how $\mathrm{s} /$ he practices educational work. This is the way we are applying boundary-work as the subject of our research. But as research on boundary-work claims itself to be scientific, the concept of boundary-work can secondly be used to reflect one's own construction of boundaries as a scientist or educational worker towards others. We are going to use this concept in both ways, which means: we will analyze the boundary-work of right-wing populists who claim to be scientific or to work educationally, and we will use it to find a scientific and critical position towards right-wing populism and thereby establish a boundary between them and us. We see the potential of boundary-work in a combined perspective that is both analytically interested in how boundaries are processed (instead of setting quick demarcations) and works on its own understanding of (in our case) science or Bildung.

Much has been written about boundaries (Lamont and Molnár 2002) as well as on right-wing populism (see Mudde and Rovira Kaltwasser 2017; Müller 2017; Mudde 2019; Möller 2020). Whereas right-wing populism is mostly the subject of political theory and political science, the boundaries between science and non-science are predominantly the subject of science studies. To analyze the boundaries between us as social and educational scientists who are engaged in secondary and higher education on the one hand, and right-wing populism that claims to be working scientifically and educationally on the other, we have to find a way to combine the results of political theory and research in science studies. To substantiate a theoretical framework that is appropriate to the specific boundary studied in this case, we start by summarizing the characteristics and the dimensions of right-wing populism elaborated in political theory. Following on, we build a bridge to science studies and especially to the sociological study of boundaries of science.

Populism is described "as a (thin) ideology that considers society to be ultimately separated into two homogenous and antagonistic groups, the pure people and the corrupt elite, and which argues that politics should be an expression of the volonté générale (general will) of the people" (Mudde 2019, p. 7-8; see also Mudde and Rovira Kaltwasser 2017). Because of this initially simple description, different political programs, actors and institutions can adopt populism. Instead of linking populism to specific actors, we consider it rather an option in the political spectrum which can be interpreted and used in different ways.

The description of populism above works as a minimal definition (Berbuir et al. 2015) and has to be further developed to capture the specifics of right-wing populism. First of all, right-wing populism combines criticism of elites with nativism. "It is an ideology that holds that states should be inhabited exclusively by members of the native group (the nation) and that non-native (or 'alien') elements, whether persons 
or ideas, are fundamentally threatening to the homogeneous nation-state" (Mudde 2019 , p. 27). We understand right-wing populist positions as directed against elites and minorities that are constructed as non-native whereas they understand themselves as expressions of an imagined will of the people (Pelinka 2013; Mudde and Rovira Kaltwasser 2017; Müller 2017). It is obvious that the contempt of elites is an ambiguous characteristic of right-wing populism: while the so called establishment is rejected, there is no essential problem with elites in right-wing populism (Müller 2017). One can even observe a right-wing populist promotion of elites, carried by the double character of this thin ideology in which the widespread authoritarian personality (Sanford et al. 1973; Altemeyer 2004) is accompanied by the socially dominant orientation (Pratto et al. 1994; Altemeyer 2004) of those who seek to be the leaders of right-wing populist movements.

Right-wing populism seems to be a success story for those who acquire a taste for this ideology: while right-wing populist parties celebrate election successes all over the world, the right-wing populist agenda around issues like immigration, islamophobia and national security drives the public debate (Buckel et al. 2017; Mudde 2019). In addition to political parties there are think tanks, publishers, publishing houses etc. working on a powerful right-wing populist narrative (for an overview of rightwing populist organisations, see Mudde 2019). This ideological interconnection of different institutions and actors, which are sometimes in competition with each other and are able to create a somehow limited diversity of opinions, suggests a right-wing populist hegemony project. ${ }^{4}$ But hegemony project is not only an analytical description of the network between different actors in the field of right-wing populism. For intellectual organizations (Mudde 2019, p. 52-54) in the right-wing populist spectrum, hegemony is the self-declared goal (Kellershohn 2016; Salzborn 2017; Wagner 2017; Mudde 2019). It is highly case relevant that education-conferences, summer/ winter schools, the publication of books and magazines-plays an important role for these organizations. Since intellectuals within a hegemony project "work towards creating an overarching political narrative" (Buckel et al. 2017, p. 17), these actors are of particular interest.

To build a bridge from the political theory of right-wing populism towards the field of science studies, we introduce three analytical dimensions postulated by Jan-Werner Müller (2017). He describes an "inner logic" (Müller 2017, p. 10; for a historical study of the inner logic of populism, see Möller 2020) of populism and coins three dimensions that capture the demarcation between populism and other forms of politics. The first and the second dimension can be summarized under the title "What Populists Say" (Müller 2017, p. 7). First, he analyses "The Logic of Populism", by which he means a special rationality, idea or imagination of the political and social world. Secondly, he analyses the content of populist claims. The third dimension is summed up under the title "What Populists do" (Müller 2017 , p. 41) and is concerned with their techniques of governing, their handling of democratic and social institutions and their manifestations in constitutions.

\footnotetext{
${ }^{4}$ Sonja Buckel et al. (2017, p. 17) define hegemony projects as "bundle of strategies that pursue similar goals", but call for further research to speak of a right-wing populist hegemony project.
} 
Of course, these three dimensions-rationality, content and institutionalization-of populism are part of a political theory and therefore limited for our needs. However, a bridge to science studies can be built, which is promising for our study of right-wing populistic boundary-work. To analyze the continuities and distinctions between the scientific and educational effords of right-wing populism and our understanding of science and education, we introduce three dimensions that are related to the political theory of populism: the first dimension focuses on social practices and institutionalizations. Second, there is a content-related dimension concerned with issues, demands and statements. A third epistemic dimension includes the rationality and the inner logic of populism. Whereas Gieryn (1983, p. 782) only distinguishes between "style and content" of the demarcation between science and non-science and therefore remains at a rhetorical level (see also Lamont and Molnár 2002), we add a differentiation pointed out by Weingart (2013). Weingart distinguishes institutional and epistemic structures (Weingart 2013), which we use to get a broader view on how right-wing populists are claiming to be scientific. To conclude our theoretical framework, we further explain the three dimensions of boundaries below.

When we focus on the institutional dimension (Weingart 2013; see also Bourdieu 1998), we analyze how right-wing populism is part of a scientific and educational process of institutionalisation. This refers not only to organisations and networks but also the practice of doing science or doing educational work (Beaufaÿs and Krais 2005; Etzemüller 2019). We are therefore interested in the efforts to be recognized as a scientific actor and educationist. Our research in this regard extends to publication media, organizations, actors and social networks among actors as well as cultural and academic events and performances during these events. The questions raised to analyze the boundary-work in its institutional dimension are: who is participating in and which institutions are part of the right-wing populist scientific and educational discourse? What are the positions and relations between the actors? How do these actors perform science and educational work?

Focussing on the content-related dimension (Gieryn 1983) of boundaries, we are interested in communications about social and educational sciences, particular issues raised and especially Bildung in the right-wing populist discours. In order to analyze the boundary-work in its content-related dimension we ask: what social and pedagogical issues do right-wing populists put on the agenda when they claim to do science or educational work?

When we focus on the epistemic dimension (Weingart 2013), we analyze how right-wing populists justify their knowledge to be true or scientific. The idea of a comparative epistemology goes back to Ludwik Flecks' (1979) analysis of thought style. In this tradition, the epistemological objects of our research are the central references (Brunkhorst 1983) that make the right-wing populist way of thinking paradigmatic (Kuhn 1962). It is about their modes of problematization (Foucault 1990) and the intellectual realm of possibilities they refer to in which they ought to find solutions to their problems. The questions asked to analyze the boundary-work in its epistemic dimension are: how does something become a scientific problem or a problem for educational work in the right-wing populist discourse? Which 
principles are the foundations for right-wing populists to distinguish truthfulness from falsehood?

\section{The case}

What are continuities between science and education on the one hand and rightwing populism on the other? We want to answer this question using the case of the 20th Winterakademie (Winter Academy), which took place at the Institut für Staatspolitik (institute for state policy) in January 2020.

The Institut für Staatspolitik (INSTAPO) is a right-wing think tank located in a small village in eastern Germany. A number of scholars (Kellershohn 2016; Salzborn 2017; Hufer 2018; Frei et al. 2019) have taken issue with this intellectual organization (Mudde 2019) of the far right. It is generally agreed that INSTAPO is located far right on the political spectrum and shows attempts to do scientific and educational work. However, to date, no study has looked specifically at its boundary-work in relation to science and education. ${ }^{5}$ The data used for this explorative analysis stems from the self-portrayal of INSTAPO on its own website as well as on the YouTube channel kanal schnellroda, print publications of the publishing house Antaios and the magazine Sezession (both of which are connected to INSTAPO) as well as the documentation of the 20th Winter Academy on YouTube. Full-text copies of publications and the texts on the website have been archived. The YouTube videos have been transcribed verbatim. A list of cited references is attached to this paper.

Our analysis is structured according to the institutional, content and epistemic dimensions elaborated above. After analyzing the continuities, the fourth and final chapter addresses the question: How can a critical distance to right-wing populism be maintained in spite of these continuities?

\subsection{Institutional dimension}

In his overview of right-wing organizations, Mudde (2019) distinguishes between parties, social movements and subcultures. He identifies intellectual organizations as one type of social movement organizations (Mudde 2019, p. 53-55). "This includes both specific organizations within the more successful political parties, which organize thematic conferences and summer schools to educate their cadres, and groups that focus exclusively on education, for example by publishing books and magazines" (Mudde 2019, p. 53). These institutions pursue a metapolitical objective. In contrast to everyday party politics, their aim is to assert their own principles in pub-

\footnotetext{
5 Since it is a characteristic of hegemony projects to differentiate themselves in specific areas (Buckel et al. 2017), we consider it important to conduct context-specific research on them. Just as the neoliberal hegemony project, for example, influences the educational system or public administration in its own areaspecific way and therefore, in scientific research, requires suitable approaches in each case, we also see the necessity to deal with the far right hegemony project in relation to science and education. This requires methodological approaches with which the far right can be analyzed in its educational and scientific claim. Our research aims to contribute to such a perspective.
} 
lic discourse and thus change society (Kellershohn 2016; Salzborn 2017; Wagner 2017). The subject of our analysis, the INSTAPO, is an intellectual organization that is not officially bound to a party.

INSTAPO, the magazine Sezession published by INSTAPO and the publishing house Antaios are strategic elements of the far right in Germany (Kellershohn 2016; Salzborn 2017; Wagner 2017; Frei et al. 2019). All of them are located in the small village of Schnellroda but woven into an international network of similar institutions: INSTAPO, Antaios and Sezession have strong connections to the so-called Nouvelle Droite in France. The conspiracy myth of the great replacement by the French author Renaud Camus, which is widespread in the far right discourse, is published in German translation at Antaios (Frei et al. 2019; Mudde 2019). The same applies to the belletristic description of the rise of the neo-fascist Casa Pound (Koch 2016; Mudde 2019) in Italy, written by Domenico Di Tullio (Wagner 2017). Furthermore, Martin Sellner, activist of the identitarian movement in Austria, belongs to the permanent circle of Sezession authors. These brief highlights should serve as an indication that the case we are looking at is interesting beyond the German context. Far right institutions that claim to do scientific and educational work are thus a challenge for science and education across national borders and specific settings.

Despite the metapolitical orientation in contrast to party politics, there are numerous bridges between INSTAPO, Sezession, Antaios and the currently most successful right-wing populist party in Germany, the AfD (Berbuir et al. 2015). The AfD first appeared in the German parliament in 2017 with $12.6 \%$ of votes and achieved strong results in some federal states. INSTAPO actors have close contact especially to the radical wing of the party (Strobel and Bruns 2016; Wagner 2017; Frei et al. 2019). Leading heads of the party have lectured at INSTAPO events or published at Antaios. ${ }^{6}$ INSTAPO and its publication organs are thus at least interwoven with the radical part of the AfD.

INSTAPO sees itself as part of the fields of research and science, education and policy advice (Kellershohn 2016). Their self-proclaimed aim is to replace what schools and universities have failed to do (INSTAPO n.d.a). The journal Sezession and the publishing house Antaios document INSTAPO events and publish books of participating as well as of other authors (Kellershohn 2016). INSTAPO lists over thirty own publications of a "Wissenschaftliche Reihe" (scientific edition) (INSTAPO n.d.b), and Antaios publishes the Staatspolitische Handbuch in the manner of handbooks and encyclopedias of scientific disciplines (for a critical analysis, see Kellershohn 2011). The cover of the publication, formatting, references and the index of persons and terms all look quite scientifical. Academic title of lecturers are highlighted on the YouTube channel kanal schnellroda, where the academies are documented and new publications announced. Conversations are usually filmed in

\footnotetext{
${ }^{6}$ Kellershohn (2016) elaborates that far right intellectuals are divided in their relationship to the AfD. The actors around INSTAPO are interested in a metapolitical perspective, one that rejects party-political compromises and relies on radical opposition. There are therefore contacts with AfD actors who cling to a fundamental opposition. Both the radical part of the AfD and the Institut für Staatspolitik are currently a so-called Verdachtsfall (suspected case) for the German Bundesamt für Verfassungsschutz (the domestic intelligence service of the Federal Republic of Germany).
} 
front of bookshelves framed by short clips with desk scenes. These are only a few examples of how INSTAPO is interwined performatively to science and education.

The annually recurring academies - the summer and winter academies - are important elements in the educational work of INSTAPO (Kellershohn 2016). The academies are aimed at pupils, students and young professionals up to the age of 35, as can be seen from the announcement of the 20th Winter Academy (INSTAPO 2019). Up to 150 participants were invited to register. The academies adopt a changing thematic focus, with the most recent Winter Academy on the subject of "Lesen" (reading). With lectures, working groups and the opportunity for informal exchange, the events follow the mode of scientific conferences or workshops. This is also made clear by the references to the academic titles of the lecturers, quoting practices, the spatial arrangements and the sequence of lecture and subsequent discussion. The academies are documented in publications, see most recently the Sezession issue on "Lektüren" (Verein für Staatspolitik e. V. 2020).

We will pick out Benedikt Kaiser's lecture at the Winter Academy (kanal schnellroda 2020a) as an example because it is particularly suitable for our research question on continuities between science and education on the one hand and right-wing populism on the other hand. Kaiser is one of the editors of Sezession, introduced on the Antaios website as a trained political scientist. Kaiser's lecture at the Winter Academy is entitled "Linke Lektüren-eine Anleitung" ("Left Reading—a Guide"). A short and edited version of his lecture has been published in the aforementioned edition of Sezession (Kaiser 2020). In his presentation Kaiser emphasizes that rightwing intellectuals like him-he speaks in the first person plural ("we") — are not "Reinwissenschaftler" ("pure scientists"). Nevertheless, he acts scientifically: books packed with post-its pile up on the lectern; scientists are a recurring reference point in his speech; the lecture is interspersed with quotations; theory and political theory are recurring catchwords (viewable on YouTube via kanal schnellroda (2020a)).

Looking at the boundary-work by INSTAPO, it is quite obvious that they try to establish institutional and performative similarities between themselves and the fields of science and education that force others to acknowledge them as scientific or educational actors. This attempt can be seen as part of their metapolitical approach and their self-description as a hegemony project (Kaiser 2020, p. 25; for a comprehensive insight, see Wagner 2017).

\subsection{Content-related dimension}

INSTAPO (n.d.a) names six subject areas which structure the work of the institute: "Staat und Gesellschaft" ("state and society"), "Politik und Identität" ("politics and identity"), "Zuwanderung und Integration" ("immigration and integration"), "Erziehung und Bildung" ("education"), "Krieg und Krise" ("war and crisis"), "Ökonomie und Ökologie" ("economy and ecology"). With regards to the subject area of "Erziehung und Bildung", scientific and political education work is described as the main concern of INSTAPO (n.d.a). Even though some research areas like identity and immigration concur with prominent issues of the far right, the topics do cover classic fields of political education and social and educational science. 
Antaios publisher and Sezession editor-in-chief Götz Kubitschek (kanal schnellroda 2020b) points out that for those who have found their way "zu unserer Denkrichtung oder Denkschule" ("our school of thought"), the Staatspolitische Handbuch provides a canon that far right followers should master. The handbook is available in five volumes: "Leitbegriffe" ("guiding concepts") (Lehnert and Weißmann 2018a); "Schlüsselwerke" ("key works") (Lehnert and Weißmann 2010); "Vordenker" ("Masterminds") (Lehnert and Weißmann 2012); "Deutsche Orte" ("German locations") (Lehnert and Weißmann 2018b); and "Deutsche Daten" ("German dates") (Lehnert 2017). In the preface to the first volume Karlheinz Weißmann (2018a, p. 9) writes: "Es [das Handbuch] ist nicht als wissenschaftliches Nachschlagewerk, sondern für den Gebrauch in der Auseinandersetzung gedacht."7 However, the entries repeatedly present themselves as scientific: for example, references to scientists and studies are mentioned to authorize any line of argumentation, and bibliographical references are linked to the entries. In this regard, the relation to science is at least ambivalent. The scientists mentioned come from very different historical eras and are set in a very loose relation to each other. Furthermore, they are mentioned alongside references to clearly non-scientific people on an equal footing. The interplay between a scientific character on the one hand and a (intended) demarcation from science on the other becomes also obvious in the preface of the second volume. The editors (Lehnert and Weißmann 2010, p. 8) characterize "Schlüsselwerke" ("key works") as not comparable to another "Werklexikon der Politikwissenschaft (davon gibt es genug)" ("encyclopaedia in political science (there are enough of them)") before they quote Ernst Robert Curtius explaining that "Schlüsselwerke" are the first step in a "lebendigen Prozess" ("living process") to become a researcher whose desire for objectivity is a habituated behaviour.

The first volume "Leitbegriffe" contains terms that can also be found in other encyclopaedias and handbooks: e.g. "Demokratie" ("democracy)", "Elite" ("elite") "Gerechtigkeit" ("justice"), "Metapolitik" ("metapolitics"), "Moderne" ("modernity"), "Vaterland" ("fatherland"), "Volk" ("people"). Not surprisingly, while none of these terms is biased on its own, the compilation of terms makes the right-wing populist character of the "Leitbegriffe" evident. This impression is substantiated by looking further at the explanations of some terms. The central references of the right-wing populist ideology "Volk" ("people") (Weißmann 2018b, p. 155-157) and "Elite" ("elite") (Weißmann 2018c, p. 39-41) are explained as follows: even though it is stated that "Volk" is a historically grown institutionalisation, the entry claims that there are ethnic homogenous groups that constitute the core population of nations. This descendant community is meant to be the "Volk". The other central reference "Elite" is drawn as an ambivalent part of the structure of modern states. On the one hand, there are numerous references to the need for elites. On the other hand, we can see an anti-elitist stance towards contemporary elites. Both explanations of the terms "Volk" and "Elite" make clear that this Handbook is strongly connected to the thin ideology of right-wing populism —which is not surprising.

The latest winter and summer academies organized by INSTAPO covered the topics "Lesen" ("Reading"), "Das politische Minimum" ("The political minimum"),

\footnotetext{
7 "The handbook is not intended as a scientific reference work, but for use in debate".
} 
"Wir und die anderen" ("We and the others") and "Die Zukunft Europas" ("The future of Europe"). More clearly than in the case of the subject areas, some of the themes are strongly related to right-wing populism while others cannot be assigned to a right-wing agenda alone. We will now focus on the subject "Lesen" of the 20th Winter Academy held in January 2020, and in particular on the lecture by Benedikt Kaiser mentioned above. Kaiser belongs to a group of authors who read social science literature-which he defines as "linke Lektüren" ("leftwing reading") - from a right-wing populist point of view in order to seek points of references (Wagner 2017). It is very evident that this approach of Kaiser and others is active boundary-work towards social and educational science. In the following, we sum up the specifics of this approach.

As Kaiser mentions in his lecture, one reason that he studies "Linke Lektüren" is that the range of topics dealt with exceeds the canon of right-wing publications. "Und hier, so meine ich, können wir durchaus anknüpfen und hier ist auch einiges für uns zu holen" (kanal schnellroda 2020a). ${ }^{8}$ In order to change reality, it would first have to be essentially understood-according to Kaiser (2020, p. 27) in his Sezession article "linke Analytiker" ("left-wing analysts") could be helpful in this regard. In his reception of authors such as Karl Marx, Marcel Mauss, Thomas Piketty and Wolfgang Streeck, Kaiser emphasizes topics such as alienation, commodification, commercialization, digitalization, globalization, nature conservation and the state. In this way, Kaiser chooses issues and authors that are widely discussed in the scientific field. He (kanal schnellroda 2020a) uses them as "Schablonen" ("template") or "Folien" ("foil") through which he confirms his own thinking-what he explicitly describes as the goal of his ausschlachtendem ("cannibalizing") approach (Kaiser 2020).

The boundary-work on the content dimension also shows a continuity with science and educational work. But this continuity is at least ambivalent when the Staatspolitische Handbuch includes terms, authors and works that clearly belong to the political far right. It is obvious here that the mixture of scientifically established themes and authors with right-wing populist niche issues and more or less unknown authors serves a purpose: the aim is to enter the field of science by being engaged in a substantive discussion. This is why we reject the reflex to develop our disagreement with right-wing populist content and will instead examine the epistemic dimension of right-wing populism more closely.

\subsection{Epistemic dimension}

Kaiser's statement that right-wing intellectuals like him are not "Reinwissenschaftler" ("pure scientists") is clearly an example of boundary-work towards science. Instead of going along with this distinction between right-wing populism and science, we have to take a closer look. First, because the continuities in the institutional and content dimensions are too strong to be ignored. Secondly, because even within science the assumption of a pure science is obsolete.

\footnotetext{
8 "And here, I think we can certainly build on that, and there is also a lot for us to get out of it.".
} 
Pierre Bourdieu in particular (1998) demonstrated the entanglement of science with other social fields, which led him to distinguish two types of scientific capital. On the one hand, there is pure scientific capital that accumulates through acknowledged contributions to scientific progress. On the other hand, there is a struggle for profane respectively political capital in the scientific field. Here the positioning in scientific institutions, leadership functions, membership in commissions etc. is combined with power over means of production (contracts, money, posts etc.) and means of reproduction (making careers). It is thus historically evident that the development of the scientific field depends on its relation to the political, economic, educational and other sectors. Therefore, instead of falling for the demarcation between science and education on the one hand and a right-wing populist epistemology that states not to be pure science on the other, we have to point out the continuity with Kaiser's self-description. No social and educational scientist is a pure scientist. Hence the central question on the epistemic dimension is not how to distinguish the episteme from the doxa once and for all, but how academics and right-wing populists are dealing with the realization that they can't be pure scientists.

The right-wing populist answer to this problem is to seek epistemic refuge in foundationalism (on foundationalism, see Marchart 2007). What is not purely scientific, apart from all the continuities with the fields of science and education, is filled with foundationalist assumptions which exclude ambiguity and self-reflection. This finding is not unmasking any hidden intent, since it is explicitly acknowledged, for example, by Kaiser himself.

As a preamble to a "Linke Lektüre" ("Left Reading") Kaiser (2020, p. 27) emphasizes that there are "schwer veränderliche Trennlinien" ("dividing lines that are difficult to change") between right-wing populist thinking and the books he reads. In his lecture at the Winter Academy, he even speaks of "unveräußerlichen Trennlinien" ("inalienable dividing lines") that should be remembered (kanal schnellroda 2020a). These dividing lines can be seen, for example, in the understanding of the term "people" ("Volk"). In an examination of Nouvelle-Droite thinker Alain de Benoist in comparison with Ernesto Laclau and Chantal Mouffe, Kaiser (2019) develops the central point: while Laclau and Mouffe understand people in terms of a demos constituted in social struggles, Benoist presupposes the people as a priori, as ethnos. A priori settings and inalienable dividing lines thus reveal foundationalising practices which evade theoretical and empirical irritability. In an exchange of letters with Götz Kubitschek, Antaios publisher and editor-in-chief of Sezession, the sociologist Armin Nassehi insists on exactly this point. For Nassehi, Kubitschek's position is not capable of discourse "weil sie den Rekurs aufs 'eigene Volk' wie eine transzendentale, also vorempirische Bedingung behandeln muss" (Nassehi 2015, p. 296, see also p. 321-328). ${ }^{9}$

The immunization against theoretical and empirical irritations becomes also evident when Kaiser gives advice on reading. In his lecture, Kaiser (kanal schnellroda 2020a) emphasizes that "left-wing reading" can, in the worst case, lead to a change in basic convictions. Therefore a reading of left-wing literature must "am besten,

\footnotetext{
9 "because it must treat the recourse to 'its own people' as a transcendental, i.e. pre-empirical condition".
} 
wenn man sie von rechts her betreibt, von einem festen Fundament aus erfolgen"10. For Kaiser, this steadfastness is also a question of character and style. Kaiser contrasts his epistemology with the biography of Henning Eichberg, one of the founding fathers of the new right in Germany (Wagner 2017). According to Kaiser, Eichberg had let himself be convinced of the opposite by reading left-wing literature. This openness to become someone else, which Kaiser sees and names as such, must be closed by a firm foundation and by an appropriate character. Instead of maintaining openness to Bildung, the aim is, in his view, "das eigene Weltbild stärker, konsistenter und auch substanzieller werden zu lassen"11 (kanal schnellroda 2020a).

With reference to the epistemic dimension, the boundary-work of right-wing populism is somewhat hesitant. Kaiser does not claim to be scientist but claims a resemblance by identifying himself not to be a "Reinwissenschaftler" ("pure scientist"). In this way, a position external to science and education extends its feelers into the field of science and education. That said, the continuities are weak in the epistemic dimension, compared to the institutional and content dimensions. This then provides us with the point of departure to find a critical position towards right-wing populism. The right-wing populist pushing-into-science and education fails from the moment any openness towards new scientific insights and Bildung is closed. The continuities on the institutional and content-related level then conceal an epistemology that is opposed to science and Bildung in its core.

\section{Conclusion. Or: Finding a critical position towards right-wing populism}

Finally, the question on how to find a critical distance from right-wing populism is addressed in two steps. First, we are concerned with a critique of the far right's understanding of science and education. Second, we self-critically turn the perspective on ourselves. By working on our own positioning as scientists and educationists, boundary work is no longer our subject but a self-reflective practice.

In his article "Why Astrology Is A Pesudoscience" Paul R. Thagard (1978) discussed the problem that despite the quick consensus that astrology is not a science, it is difficult to justify it. In his argumentation he explores various demarcation criteria, such as the origin of a science, its physical foundation, and its verifiability and falsifiability, none of which enable him to come to a clear demarcation. Thagard then shifts his focus to the social and historical context as well as to practices in order to distinguish pseudoscience from science. This perspective can be compared to the concept of boundary-work, since here, too, boundaries are established through social practices, and can be changed by them. Thagard (1978, p. 227-228) identifies two conditions to distinguish science from pseudoscience.

A theory or discipline which purports to be scientific is pseudoscientific if and only if:

\footnotetext{
10 "be done best if operated from the right, from a firm foundation".

11 "to make one's own world view stronger, more consistent and also more substantial".
} 
1) it has been less progressive than alternative theories over a long period of time, and faces many unsolved problems; but

2) the community of practitioners makes little attempt to develop the theory towards solutions of the problems, shows no concern for attempts to evaluate the theory in relation to others, and is selective in considering confirmations and disconfirmations.

We use these criteria to position ourselves critically towards the right-wing populist attempts to do scientific and educational work. INSTAPO practices pseudoscience first, because the approaches pursued are less progressive than alternative approaches. Kaiser (kanal schnellroda 2020a) himself confirms this when he points out that left-wing authors - by which he refers to social scientists-work on a much wider range of topics while right-wing thinking focuses on a few fixed points. Secondly, our study provides evidence that new-right actors do little to further develop their own theories, to critically question them in contrast to others, and to selectively confirm their own self-understanding. In his lecture, Kaiser (kanal schnellroda 2020a) himself emphasizes that he is interested in selective reading. His insistence on a solid foundation, which is not at disposal but in principle should always only be confirmed, highlights his view that a critical evaluation is not desired. Likewise, it is very difficult to speak of Bildung when a certain foundation is set as absolute and authorities in the field determine how it can be further secured, for example through a particular reading canon. Kaiser's remarks here give expression to a programme of indoctrination rather than Bildung because the possibility of transformational processes (Koller 2017; Rieger-Ladich 2019) is denied.

Our findings suggest that attempts by right-wing populists to do scientific or educational work do fail in the epistemic dimension, regardless of the similarities in the institutional and content-related dimensions. This is why we can use the differences between science/Bildung and right-wing populism in the epistemic dimension as a starting point for our self-critical turn to question our own practice.

With reference to the epistemic dimension, the question how we can make a permanent habit of reflecting on the missing foundation in science and Bildung remains the key challenge. We would encourage researchers and educationalists to reflect on their own a priori settings and firm foundations, the denial of change in one's own thought style, which are ultimately not compatible with our concepts of research and Bildung. Historical epistemology, in particular, shows us that we "must object in principle that nobody has either a feeling for, or knowledge of, what physically is possible or impossible. What we feel to be an impossibility is actually mere incongruence with our habitual thought style" (Fleck 1979, p. 48). It follows from this that in science and education we have to promote a pluralistic approach (Thompson 2020; see also Haker 2020), in at least two ways: first, a pluralistic approach acknowledges different habitual thought styles and gives them the opportunity to reveal their knowledge. Secondly, it encourages every researcher and educational worker to adopt a change in perspective once in a while.

Regarding the content dimension, it seems advisable not to get bogged down too quickly in a discussion about content. Right-wing populist publications may provoke and-in any discussion of terms - encourage to contradict. A first reflex is to work on 
concepts and to oppose them with a truly scientific consideration. The problem with this reflex is twofold: first, the concept of boundary-work allows us to see clearly that when we enter a discussion with right-wing populist positions, we let this positon enter the fields of science and education vice versa. We would thereby promote the ability of right-wing populist intellectual and educational organisations to perform science and educational work. Secondly, when we focus on the content too early, we would enter a debate that lacks a common epistemology. The underlying problem is then being overlooked. It is therefore clear to us that from a scientific point of view it makes no sense to discuss with right-wing populists at conferences, podiums or in anthologies. The only outcome of this would be that their foundationalist positions are repeated once again, now in a scientific context. No scientific value can be expected from such events.

The situation is different in teaching and learning situations. If right-wing populist positions are represented here, there is an immediate need to deal with right-wing populist ways of thinking and beliefs, and both teachers and students are under pressure to act. One possible way for us to deal with such situations is not to lose sight of the genesis of content when talking about its validity. In our view, the Jenaer Erklärung (Jena Declaration), written on the occasion of the 112th Annual Meeting of the German Zoological Society, is a good example of how to discuss content (as well as the positioning of the participating biologists) in a way that is not detached from its historicity. The authors (Fischer et al. 2019, p. 2) conclude that "the concept of race is the result of racism, not its prerequisite." In their argumentation, current findings in biology are intertwined with a genealogical approach-and it is precisely in this way that the authors force themselves to adopt a perspective that does not stop at a selective range of findings. Instead of opposing the right-wing position that there are human races, or ethno-pluralist varieties of this position (see, for example, the corresponding manual entries in Lehnert and Weißmann 2018a) exclusively with a "no" and thus pursuing an eternal "yes-no game", another possibility opens up. The debate about content can be focused on the historical emergence of racist thinking, in order to counteract the threat of polarization on the one hand, and on the other, to focus the discussion on a broad interdisciplinary reception of the state of research (on racism, not on races), thus marking the question of the existence of races as non-scientific. In addition to such a genealogical perspective, Paul Mecheril (1999) highlights the necessity of reflecting on the (possible) impact of research in a historically informed way, since the everyday life of people is affected by research directly (in a technological sense) or indirectly (in a discursive sense). Since knowledge is not only conditioned by its genesis but always triggers further developments, ethical arguments can or must be included. Even if the use of scientific knowledge cannot be controlled (Otterspeer and Haker 2019), it does not have to be left to arbitrariness, because scientific knowledge without ethical reflection and criticism is a danger in its unquestioned use (Mecheril 1999; see also de Lagasnerie 2018).

On the institutional dimension, the question arises whether a science that generates relevance via a certain performance and institutionalization contributes to the self-destruction of science (Etzemüller 2019) because the performance puts style over substance. As we have shown above, it is quite easy for right-wing populism to 
enter the academic field performatively. In addition to the analysis of the "Winterakademie" we have shown how right-wing populist positions can build on the public presentation of the Progress in International Reading Literacy Study 2016 at a press conference involving representatives from science and politics in Germany (Otterspeer and Haker 2019; Haker and Otterspeer 2021). Generalizing our research on this case, we see the problem in that an overemphasis on performance and institutionalisation pushes the epistemic decisions-which mark the limits of knowledge-into the background. Scientific practice and relevance can thus be generated-or better: simulated-through a certain performance and institutionalization. In a self-critical twist, we conclude that there is a need for formats of scientific communication that do not establish and support authority and authorities, like in typical academic lectures where one person is speaking and others are listening. If science and educational work seek to position themselves in a critical way towards the authoritarian character of right-wing populism, they have to find other ways of communication. Bourdieu (1998, p. 63), for example, proposes discursive settings that function as a collective reflexion. He has borrowed this concept from the feminist movement and is therefore an example that universities have to be open institutions, that are not completely isolated of political discourses. We see a further possibility of establishing self-critical epistemological practices in a concretization of research-based learning (Jenkins and Healey 2009), which is becoming increasingly fashionable in academic teaching as well as in school education and other educational institutions but far from having being widely accepted and understood consistently. This concept urges students to work on epistemological problems themselves, to the extent that students are seriously involved in research and that their results, if of appropriate quality, are incorporated into the scientific discourse. It thus provides an opportunity for students and educationists to use seminars for reflexive (self-)criticism. While Bourdieu and research-based learning serve as examples, it always remains an open question as to how we are working on the institutionalisation of debates in academia and in educational work. This ist why Thompson (2020, p. 9) argues: "Thus, the conditions of exchange have to be the subject of constant reflection. What makes for a better or worse discursive exchange? What are the appropriate criteria for such a discussion?"

Our boundary-work towards right-wing populism is therefore first of all an occasion for us to subject our own practices to critical reflection. Science and Bildung share the characteristics that they are always a movement between closure, e.g. when defining terms or setting up models, and opening, e.g. when starting a research project or learning process without prejudging the outcome. While the closure of contingency is a requirement in presenting results, we advocate the opening up of contingency as mandatory for research and Bildung. Only in this way can science and Bildung persist without becoming dogma. Even though there is always a dogmatic tendency in science (Bourdieu 1975), theories, methodologies and methods are limited by their historical, spatial and cultural location (Lindemann 2016; Haker 2020). But research and Bildung depend on us being ready to say that I myself have made a mistake and therefore have to change my point of view (Rheinberger 2019). Bluntly speaking, this attitude is the common ground of science and Bildung and it is that attitude that is missing in right-wing populism. Science itself, 
paraphrasing Koller, must be understood as a process of Bildung. "In dealing with its object, it needs to remain open to confusion and experiences of the unfamiliar that provoke a transformation of one's own way of relation to the world and the self-i.e., a rephrasing of one's own theoretical, methodological or other categories and presuppositions" (Koller 2017, p. 41).

Open Access This article is licensed under a Creative Commons Attribution 4.0 International License, which permits use, sharing, adaptation, distribution and reproduction in any medium or format, as long as you give appropriate credit to the original author(s) and the source, provide a link to the Creative Commons licence, and indicate if changes were made. The images or other third party material in this article are included in the article's Creative Commons licence, unless indicated otherwise in a credit line to the material. If material is not included in the article's Creative Commons licence and your intended use is not permitted by statutory regulation or exceeds the permitted use, you will need to obtain permission directly from the copyright holder. To view a copy of this licence, visit http://creativecommons.org/licenses/by/4. $0 \%$

\section{References}

\section{Cited material}

INSTAPO - Institut für Staatspolitik (2019). 20. Winterakademie in Schnellroda: Thema "Lesen". https:// staatspolitik.de/20-winterakademie-in-schnellroda-thema-lesen/. Accessed 11 June 2020.

INSTAPO - Institut für Staatspolitik Arbeitsgebiete (n.d.a). https://staatspolitik.de/arbeitsgebiete/. Accessed 11 June 2020.

INSTAPO - Institut für Staatspolitik Studien (n.d.b). https://staatspolitik.de/studien/. Accessed 11 June 2020.

Kaiser, B. (2019). Blick nach Links. Schnellroda: Antaios.

Kaiser, B. (2020). Linke Lektüren. Eine Anleitung. Sezession, 94, 25-29.

Kanal schnellroda (2020a). „Linke Lektüren - eine Anleitung“ Benedikt Kaiser auf der 20. Winterakademie des IfS. https://www.youtube.com/watch? $\mathrm{v}=$ du $8 \mathrm{bkFIchOE \& t}=2732 \mathrm{~s}$. Accessed 18 June 2020.

Kanal schnellroda (2020b). „Sezession \#94“ Götz Kubitschek und Benedikt Kaiser präsentieren das „Lektüren-Heft". This video is currently (2020, October 14) no longer available on YouTube, but a copy can be requested from the authors.

Lehnert, E. (Ed.). (2017). Deutsche Daten. Schnellroda: Antaios.

Lehnert, E., \& Weißmann, K. (Eds.). (2010). Schlüsselwerke. Schnellroda: Antaios.

Lehnert, E., \& Weißmann, K. (Eds.). (2012). Vordenker. Schnellroda: Antaios.

Lehnert, E., \& Weißmann, K. (Eds.). (2018a). Leitbegriffe. Schnellroda: Antaios.

Lehnert, E., \& Weißmann, K. (Eds.). (2018b). Deutsche Orte. Schnellroda: Antaios.

Verein für Staatspolitik e. V. (2020). Lektüren. Sezession, 94.

Weißmann, K. (2018a). Vorwort. In E. Lehnert \& K. Weißmann (Eds.), Leitbegriffe (pp. 7-9). Schnellroda: Antaios.

Weißmann, K. (2018b). Volk. In E. Lehnert \& K. Weißmann (Eds.), Leitbegriffe (pp. 155-157). Schnellroda: Antaios.

Weißmann, K. (2018c). Elite. In E. Lehnert \& K. Weißmann (Eds.), Leitbegriffe (pp. 39-41). Schnellroda: Antaios.

\section{Literature}

Altemeyer, B. (2004). The other "authoritarian personality". In J. T. Jost \& J. Sidanius (Eds.), Political psychology. Key readings (pp. 85-107). New York: Psychology Press.

Amlinger, C. (2020). Rechts dekonstruieren. Die Neue Rechte und ihr widersprüchliches Verhältnis zur Postmoderne. Leviathan, 48(2), 318-337.

Andresen, S. (2018). Rechtspopulistische Narrative über Kindheit, Familie und Erziehung. Zeitschrift für Pädagogik, 64(6), 768-787. 
Beaufaÿs, S., \& Krais, B. (2005). Doing Science - Doing Gender. Die Produktion von WissenschaftlerInnen und die Reproduktion von Machtverhältnissen im wissenschaftlichen Feld. Feministische Studien, 23(1), 82-99.

Berbuir, N., Lewandowsky, M., \& Siri, J. (2015). The AfD and its sympathisers: finally a right-wing populist movement in Germany? German Politics, 24(2), 154-178.

Bourdieu, P. (1975). The specificity of the scientific field and the social conditions of the progress of reason. Social Science Information, 14(6), 19-47.

Bourdieu, P. (1998). Vom Gebrauch der Wissenschaft. Für eine klinische Soziologie des wissenschaftlichen Feldes. Konstanz: UVK.

Brunkhorst, H. (1983). Paradigmakern und Theoriedynamik der kritischen Theorie der Gesellschaft. Soziale Welt, 34(1), 22-56.

Buckel, B., Georgi, F., Kannankulam, J., \& Wissel, J. (2017). The European border regime in crisis. Theory, methods and analyses in critical European studies. Berlin: Rosa-Luxemburg-Stiftung.

Czollek, M. (2018). Desintegriert euch! München: Hanser.

De Lagasnerie, G. (2018). Denken in einer schlechten Welt. Berlin: Matthes \& Seitz.

Etzemüller, T. (2019). "It's the performance, stupid". Performanz $\rightarrow$ Evidenz: Der Auftritt in der Wissenschaft. In T. Etzemüller (Ed.), Der Auftritt. Performanz in der Wissenschaft (pp. 9-43). Bielefeld: transcript.

Fischer, M.S., Hoßfeld, U., Krause, J., \& Richter, S. (2019). Jena Declaration The concept of race is the result of racism, not its prerequisite. https:/www.uni-jena.de/unijenamedia/universit\%C3\%A4t/ abteilung+hochschulkommunikation/presse/jenaer+erk1\%C3\%A4rung/jenaer_erklaerung_en.pdf. Accessed 14 Oct 2020.

Fleck, L. (1979). Genesis and development of a scientific fact. Chicago: University of Chicago Press.

Foucault, M. (1990). Was ist Aufklärung? In E. Erdmann, R. Forst \& A. Honneth (Eds.), Ethos der Moderne. Foucaults Kritik der Aufklärung (pp. 35-54). Frankfurt a.M., New York: Campus.

Frei, N., Maubach, F., Morina, C., \& Tändler, M. (2019). Zur Rechten Zeit. Wider die Rückkehr des Nationalismus. Berlin: Ullstein.

Gieryn, T.F. (1983). Boundary-work and the demarcation from non-science: strains and interests in professional ideologies of scientists. American Sociological Review, 48(6), 781-795.

Gieryn, T.F. (1999). Cultural boundaries of science. Credibility on the line. Chicago: University of Chicago Press.

Haker, C. (2020). Immanente Kritik soziologischer Theorie. Auf dem Weg in ein pluralistisches Paradigma. Bielefeld: transcript.

Haker, C., \& Otterspeer, L. (2021). Empirische Bildungsforschung als Rechtfertigung rechtspopulistischer Angst. Zur gegenwartsdiagnostischen Verwendung von Large-Scale-Assessments. In C. Thompson, J. Zirfas, W. Meseth \& T. Fuchs (Eds.), Erziehungswirklichkeiten in Zeiten von Angst und Verunsicherung (pp. 169-189). Weinheim: Beltz Juventa.

Hampe, M. (2016). Katerstimmung bei den pubertären Theoretikern. DIE ZEIT, 52, 48.

Hufer, K.-P. (2018). Neue Rechte, altes Denken. Ideologie, Kernbergiffe und Vordenker. Weinheim: Beltz Juventa.

Jenkins, A., \& Healey, M. (2009). Developing the student as a researcher through the curriculum. CETL Journal, 1(2), 3-15.

Kellershohn, H. (2011). Dem Leben dienen? Anmerkungen zum „Staatspolitischen Handbuch“ des „Instituts für Staatspolitik“. DISSkursiv Blog: Notizen, Links, Meinungen. http://www.disskursiv.de/2011/ 05/17/dem-leben-dienen/. Accessed 11 Oct 2020.

Kellershohn, H. (2016). Das Institut für Staatspolitik und das jungkonservative Hegemonieprojekt. In S. Braun, A. Geisler \& M. Gerster (Eds.), Strategien der extremen Rechten. Hintergründe - Analysen - Antworten (pp. 439-467). Wiesbaden: Springer VS.

Koch, H. (2016). Casapound Italia. The fascist hybrid. In M. Fielitz \& L. Lotte (Eds.), Trouble on the far right. Contemporary right-wing strategies and practices in Europe (pp. 79-85). Bielefeld: transcript.

Koller, H.-C. (2017). Bildung as a transformative process. In A. Laros, T. Fuhr \& E. W. Taylor (Eds.), Transformative learning meets Bildung. An international exchange (pp. 33-42). Rotterdam: Sense Publishers.

Kuhn, T. S. (1962). The structure of scientific revolutions. Chicago: University of Chicago Press.

Lamont, M., \& Molnár, V. (2002). The study of boundaries in social sciences. Annual Review of Sociology, 28, 167-195.

Leo, P., Steinbeis, M., \& Zorn, D.-P. (2017). Mit Rechten reden. Ein Leitfaden. Stuttgart: Klett-Cotta.

Lindemann, G. (2016). Das Soziale von seinen Grenzen her denken. Weilerswist: Velbrück. 
Marchart, O. (2007). Post-foundational political thought: political difference in Nancy, Lefort, Badiou and Laclau. Edinburgh: Edinburgh University Press.

Mecheril, P. (1999). Wer spricht und über wen? Gedanken zu einem (re-) konstruktiven Umgang mit dem Anderen des Anderen in den Sozialwissenschaften. In W.-D. Bukow \& M. Ottersbach (Eds.), Fundamentalismusverdacht. Plädoyer für eine Neuorientierung der Forschung im Umgang mit allochthonen Jugendlichen (pp. 231-266). Wiesbaden: Springer.

Möller, K. (2020). Volksaufstand und Katzenjammer. Zur Geschichte des Populismus. Berlin: Wagenbach.

Mudde, C. (2019). The far right today. Cambridge: Polity Press.

Mudde, C., \& Kaltwasser, R.C. (2017). Populism: a very short introduction. New York: Oxford University Press.

Müller, J.-W. (2017). What is populism? London: Penguin Books.

Nassehi, A. (2015). Die Letzte Stunde der Wahrheit. Warum rechts und links keine Alternativen mehr sind und Gesellschaft ganz anders beschrieben werden muss. Hamburg: Murmann.

Otterspeer, L., \& Haker, C. (2019). Empirische Bildungsforschung im Wirbel unmittelbarer Rezeption. Ein kritischer Reflexionsanstoß. Zeitschrift für Pädagogik, 65(5), 769-788.

Pelinka, A. (2013). Right-wing populism: concept and typology. In R. Wodak, M. Khosravinik \& B. Mral (Eds.), Right-wing populism in Europe. Politics and discourse (pp. 3-22). London: Bloomsbury.

Pratto, F., Sidanius, J., Stallworth, L. M., \& Malle, B. F. (1994). Social dominance orientation: a personality variable predicting social and political attitudes. Journal of Personality and Social Psychology, 67(5), $741-763$.

Rheinberger, H.-J. (2019). Thoughts about Boundaries of Knowledge. In Zentrum für interdisziplinäre Forschung Bielefeld (Ed.), Die Grazie der Erkenntnisgrenze. Grace at the Boundary of Knowledge (pp. 12-15). Bielefeld: transcript.

Rieger-Ladich, M. (2019). Bildungstheorien zur Einführung. Hamburg: Junius.

Rödel, S.S. (2020). (Erwachsenen-)Bildung in Zeiten rechtsgerichteter Metapolitik - Für eine Re-Politisierung der Erziehungswissenschaft und Erwachsenenbildungswissenschaft. Debatte. Beiträge zur Erwachsenenbildung, 3(2), (in press).

Salzborn, S. (2017). Angriff der Antidemokraten. Die völkische Rebellion der Neuen Rechten. Weinheim: Beltz Juventa.

Sanford, R. N., Adorno, T.W., Frenkel-Brunswik, E., \& Levinson, D. J. (1973). Die Messung antidemokratischer Züge in der Charakterstruktur. In T.W. Adorno (Ed.), Studien zum Autoritären Charakter (pp. 37-102). Frankfurt am Main: Suhrkamp.

Strobel, N., \& Bruns, J. (2016). Preparing for (intellectual) civil war. The new right in Austria and Germany. In M. Fielitz \& L. L. Laloire (Eds.), Trouble on the far right. Contemporary right-wing strategies and practices in Europe (pp. 105-110). Bielefeld: transcript.

Strohschneider, P. (2017). Über Wissenschaft in Zeiten des Populismus. Rede anlässlich der Festveranstaltung im Rahmen der Jahresversammlung der DFG am 4. Juli 2017 in Halle (Saale). https://www.dfg. de/download/pdf/dfg_im_profil/reden_stellungnahmen/2017/170704_rede_strohschneider_festver anstaltung.pdf. Accessed 11 June 2020.

Thagard, P. R. (1978). Why astrology is a pseudoscience. Proceedings of the Biennial Meeting of the Philosophy of Science Association, 1, 223-234.

Thole, W. (2020). Problematische Ablehungskonstruktionen. Sozial Extra, 44, 107-112. https://doi.org/10. 1007/s12054-020-00269-4.

Thompson, C. (2020). Debating academic freedom. Educational-philosophical premises and problems. Education Philosophy and Theory. https://doi.org/10.1080/00131857.2020.1773796.

Vogelmann, F., Minnetian, C., \& Herder, J. (2019). „Es gibt keine Wahrheit“ kann nicht die Antwort sein. diskurs, 4, 46-59.

Wagner, T. (2017). Die Angstmacher. 1968 und die Neuen Rechten. Berlin: Aufbau.

Waller, R., Hodge, S., Holford, J., Milana, M., \& Webb, S. (2017). Political populism and adult education. International Journal of Lifelong Education, 36(4), 383-386.

Weingart, P. (2013). Wissenschaftssoziologie. Bielefeld: transkript.

Publisher's Note Springer Nature remains neutral with regard to jurisdictional claims in published maps and institutional affiliations. 